\title{
Prevalence of submicroscopic malaria infection in immigrants living in Spain
}

Isabel Fradejas' ${ }^{1}$, José Miguel Rubio², Ariadna Martín-Díaz' , Juan María Herrero-Martínez³, José Manuel Ruiz-Giardin ${ }^{4}$, Gerardo Rojo-Marcos ${ }^{5}$, María Velasco ${ }^{6}$, María Calderón-Moreno7, José Manuel Azcona-Gutierrez ${ }^{8}$, Francisco Jesús Merino ${ }^{9}$, Belén Andrés Olmo ${ }^{10}$, María Espinosa ${ }^{3}$, María Cuadrado ${ }^{11}$, Esther González-Monte ${ }^{12}$, Jerónimo Jaqueti ${ }^{4}$, Juan Cuadros ${ }^{5}$, Carolina Campelo6, Alberto Delgado-Iribarren ${ }^{6}$, Pablo Martín-Rabadán , Concepción García-García ${ }^{8}$, María Ángeles Martín-Laso9 , Beatriz Valle-Borrego ${ }^{10}$, María Coral García ${ }^{10}$, Manuel Lizasoaín ${ }^{13}$ and Ana Pérez-Ayala ${ }^{1 *}$ (i)

\begin{abstract}
Background: The importance of submicroscopic malaria infections in high-transmission areas could contribute to maintain the parasite cycle. Regarding non-endemic areas, its importance remains barely understood because parasitaemia in these afebrile patients is usually below the detection limits for microscopy, hence molecular techniques are often needed for its diagnosis. In addition to this, the lack of standardized protocols for the screening of submicroscopic malaria in immigrants from endemic areas may underestimate the infection with Plasmodium spp. The aim of this study was to assess the prevalence of submicroscopic malaria in afebrile immigrants living in a non-endemic area.

Methods: A prospective, observational, multicentre study was conducted. Afebrile immigrants were included, microscopic observation of Giemsa-stained thin and thick blood smears, and two different molecular techniques detecting Plasmodium spp. were performed. Patients with submicroscopic malaria were defined as patients with negative blood smears and detection of DNA of Plasmodium spp. with one or both molecular techniques. Demographic, clinical, analytical and microbiological features were recorded and univariate analysis by subgroups was carried out with STATA v15.
\end{abstract}

Results: A total of 244 afebrile immigrants were included in the study. Of them, 14 had a submicroscopic malaria infection, yielding a prevalence of 5.7\% (95\% confidence interval 3.45-9.40). In 71.4\% of the positive PCR/negative microscopy cases, Plasmodium falciparum alone was the main detected species (10 out of the 14 patients) and in 4 cases (28.6\%) Plasmodium vivax or Plasmodium ovale were detected. One patient had a mixed infection including three different species.

Conclusions: The prevalence of submicroscopic malaria in afebrile immigrants was similar to that previously described in Spain. Plasmodium vivax and P. ovale were detected in almost a third of the submicroscopic infections. Screening protocols for afebrile immigrants with molecular techniques could be useful for a proper management of these patients.

Keywords: Plasmodium, Afebrile malaria, Submicroscopic parasitaemia, Immigrant, Tropical medicine

\footnotetext{
*Correspondence: anpayala@hotmail.com

1 Department of Clinical Microbiology, Hospital Universitario 12 de

Octubre, Madrid, Spain

Full list of author information is available at the end of the article
} 


\section{Background}

Malaria remains the most important parasitic infection for humans, causing about 2000 deaths per day, especially in African children younger than 5 years old [1]. An estimated 216 million cases of malaria were reported worldwide in 2017, being the African Region the most affected area, with $90 \%$ of the documented Plasmodium infections [2]. Although the number of deaths had decreased until 2015, over the last 3 years, this number has remained stable [2], hence Plasmodium infections, and especially those caused by Plasmodium falciparum are still one of the most important tropical health problems.

Outside endemic areas, imported clinical malaria is a well-known disease; in 2017 more than 8000 imported malaria cases were reported in immigrants and travellers in European Union countries [3], of which 748 occurred in Spain [4]. In this regard, immigrants, including newly arrived immigrants and immigrants visiting friends and relatives (VFRs), account for most of the imported malaria cases in developed countries [5]. They often have milder symptoms and lower parasite loads than recently arrived travellers due to their semi-immunity. This immune response is a result of continuous exposure to malaria in the past and plays a key role in controlling the infection and protecting them from clinical disease $[6,7]$. While management of clinical malaria is well-established in protocols in several developed countries [8,9], submicroscopic infections are not usually discussed.

In endemic countries, including high-level and lowlevel transmission areas, low-density infections seems to be important for the maintenance of malaria transmission [10-12], as they can act as silent reservoirs of Plasmodium spp. [13-15]. Using mathematical models, the importance of treating asymptomatic population in the global control of the infection rather than only focusing on symptomatic patients has been postulated [16]. Some authors raise the issue of potential reintroduction of malaria in non-endemic areas, such as Spain where the vector is present [17], but whether submicroscopic infections have a role to play in the epidemiology of malaria in non-endemic countries remains unclear. Also, the prevalence of submicroscopic malaria among immigrants is unknown, and it is not clear if systematic screening or systematic treatment of immigrants from endemic areas would be necessary [18].

Furthermore, in addition to the importance of diagnosing mixed infections with potentially latent species like Plasmodium vivax and Plasmodium ovale, some studies suggest that submicroscopic cases are more likely to have lower levels of platelets and haemoglobin than noninfected patients, as well as higher rates of malnutrition, anaemia and thrombocytopaenia [19-21].
As for laboratory diagnostic methods, while microscopic observation of thick and thin blood smears and rapid diagnostic tests (RDTs) remain the most extended diagnostic techniques, they are insufficiently sensitive in patients with a low level parasitaemia. Hence, polymerase chain reaction (PCR) has proved to be an important tool not only to differentiate Plasmodium species observed in microscopy smears but also to diagnose the above-mentioned patients in recent and long-term immigrants [22].

The aim of this study was to estimate the prevalence of submicroscopic malaria infection among afebrile immigrants in Spain as well as to describe the demographical, clinical and analytical features of these patients.

\section{Methods}

\section{Study design}

A prospective, observational, multicentre study was conducted. Patients were enrolled at different settings in Madrid (Hospital Universitario 12 de Octubre, Hospital Universitario de Fuenlabrada, Hospital Universitario Príncipe de Asturias, Hospital Universitario Gregorio Marañón, Hospital Universitario Severo Ochoa, Hospital Universitario de Getafe and Hospital Universitario Fundación Alcorcón) and La Rioja, Spain (Hospital de San Pedro) between January 2015 and February 2018.

\section{Participants}

Patients from endemic malaria countries (according to CDC Yellow Book criteria [23] attending Internal Medicine, Infectious/Tropical Diseases and Emergency Services of the above-mentioned hospitals, with and without clinical suspicion of malaria were initially evaluated for inclusion in the study. They were all routinely tested for malaria (diagnostic routine testing is explained in "Diagnostic methods" section). Patients without parasites in the blood smears were eligible for the study and those who agreed to be included were provided with a written informed consent.

\section{Inclusion criteria}

All following criteria had to be fulfilled:

1. Age over 18 years-old.

2. No travels to malaria endemic areas in the month before inclusion.

3. No malaria prophylaxis intake in the month before inclusion.

4. Absence of reported fever or measured axillary temperature above $37.0^{\circ} \mathrm{C}$ in the previous $24 \mathrm{~h}$. 


\section{Diagnostic methods}

A total volume of $5 \mathrm{ml}$ venipuncture blood was collected from all included patients and routinely processed at each setting. Microscopic observation of Giemsa-stained thin and thick blood smears were routinely performed by well-trained staff at each centre. All samples were also sent to the Microbiology Service of Hospital Universitario 12 de Octubre where thick and thin smears were observed by the same microscopist for all samples and a commercial real-time PCR (FTD-Malaria, Fast-Track Diagnostics) detecting Plasmodium spp. was performed. When this PCR was positive, a differential real-time PCR detecting Plasmodium malariae, $P$. falciparum, $P$. vivax and $P$. ovale was performed (FTD Malaria Differentiation, Fast-Track Diagnostics). In addition to this, blood samples were sent to the National Centre of Microbiology (Insitituto de Salud Carlos III, Majadahonda, Spain) where a multiplex nested PCR detecting the four Plasmodium species was performed to validate the commercial PCR (results already published) [24].

\section{Patient classification}

Patients were classified according to a composite goldstandard reference method [25]. Patients with submicroscopic malaria were defined as patients with negative blood smears and detection of deoxyribonucleic acid (DNA) of Plasmodium spp. with one or both molecular techniques. When discordant results were obtained with both PCRs, patients with a positive result in at least one PCR were considered cases of submicroscopic malaria. Anti-malarial treatment was offered to all submicroscopic malaria cases. Malaria was ruled out when both molecular techniques were negative.

\section{Statistical analysis}

Socio-demographical, epidemiological, analytical and clinical features were recorded using Redcap (Research Electronic Data Capture) software. One clinician from each hospital had access to the Redcap and was in charge of the database.

Leukopaenia was defined as $<3 \times 10^{3}$ leukocytes $/ \mathrm{mm}^{3}$, thrombocytopaenia was defined as $<150 \times 10^{3}$ platelets/ $\mathrm{mm}^{3}$ and anaemia was defined as haemoglobin level below $13 \mathrm{mg} / \mathrm{dl}$ for men and below $12 \mathrm{mg} / \mathrm{dl}$ for women. Submicroscopic malaria prevalence was calculated as number of patients with submicroscopic malaria/total number of patients included in the study. $95 \%$ confidence interval for uncertainty was calculated.

Analysis by subgroups was carried out following a univariate analysis to evaluate association of sociodemographical, clinical and analytical variables. Kolmogorov-Smirnov and Shapiro-Wilk tests were performed to assess the normal distribution of the analysed variables. Student's t-test and Chi-square test were performed for continuous and categorical variables with normal distribution. Mann Whitney U-test and Fisher's exact tests were performed when variables did not fit normal distribution.

Data analysis was performed with STATA v15 for macOS (StataCorp, Texas, USA).

\section{Results}

Of the 367 initially evaluated patients, 109 (29.7\%) had a positive blood smear and 24/109 (22.0\%) were afebrile. These 109 patients were excluded from the present study, but their socio-demographic features are detailed in Additional file 1: Table S1, Additional file 2: Table S2, Additional file 3: Table S3 and Additional file 4: Table S4. A total of 244 patients were included in the study (Fig. 1), $132(54.1 \%)$ were male and median age at the time of consultation was 41 years (interquartile range [IQR]: 33-48). The majority (224: 91.8\%) was from sub-Saharan Africa, being Equatorial Guinea and Mali the main countries of origin (33.3 and $29.3 \%$, respectively); median time of residence in Spain until consultation was 11.1 years (IQR: 5.7-16.2). Eighty-six (35.3\%) had returned at least once to an endemic area since first arrival in Spain and 60 of these 86 patients had traveled to endemic area in the year before consultation. Only 14 of these $86(16.3 \%)$ patients that had returned to endemic area had taken anti-malarial chemoprophylaxis. Median time since last travel to an endemic area, in those who had not taken anti-malarial chemoprophylaxis was 6.2 months (IQR: 3.5-9.4). Of the 244 patients, 104 (57.1\%) referred a previous episode of malaria. Socio-demographic, epidemiological, clinical and analytical features of the total population and univariate analysis by subgroups are shown in Tables $1,2,3$ and 4.

Fourteen patients were defined as submicroscopic malaria cases by PCR, yielding a prevalence of 5.7\% (95\% confidence interval 3.45-9.40). In 230 patients (94.3\%) all microbiological tests for malaria were negative. Although the associations were not statistically significant, submicroscopic malaria cases had shorter time of residence in Spain than negative patients (8.9 years in submicroscopic malaria cases vs 11.3 years in negative patients, $P=0.163$ ) as well as shorter time since last travel to endemic area (4.0 months in submicroscopic malaria cases vs 6.6 months in negative patients, $P=0.170)$. Immigrant screening $(42.9 \%$ in submicroscopic malaria cases vs $14.4 \%$ in negative patients) and myalgia (14.3\% in submicroscopic malaria cases vs $1.7 \%$ in negative patients) were the reasons for consultation associated to submicroscopic malaria cases $(P=0.013$ and $P=0.040)$. Filariasis was also associated with submicroscopic malaria patients 


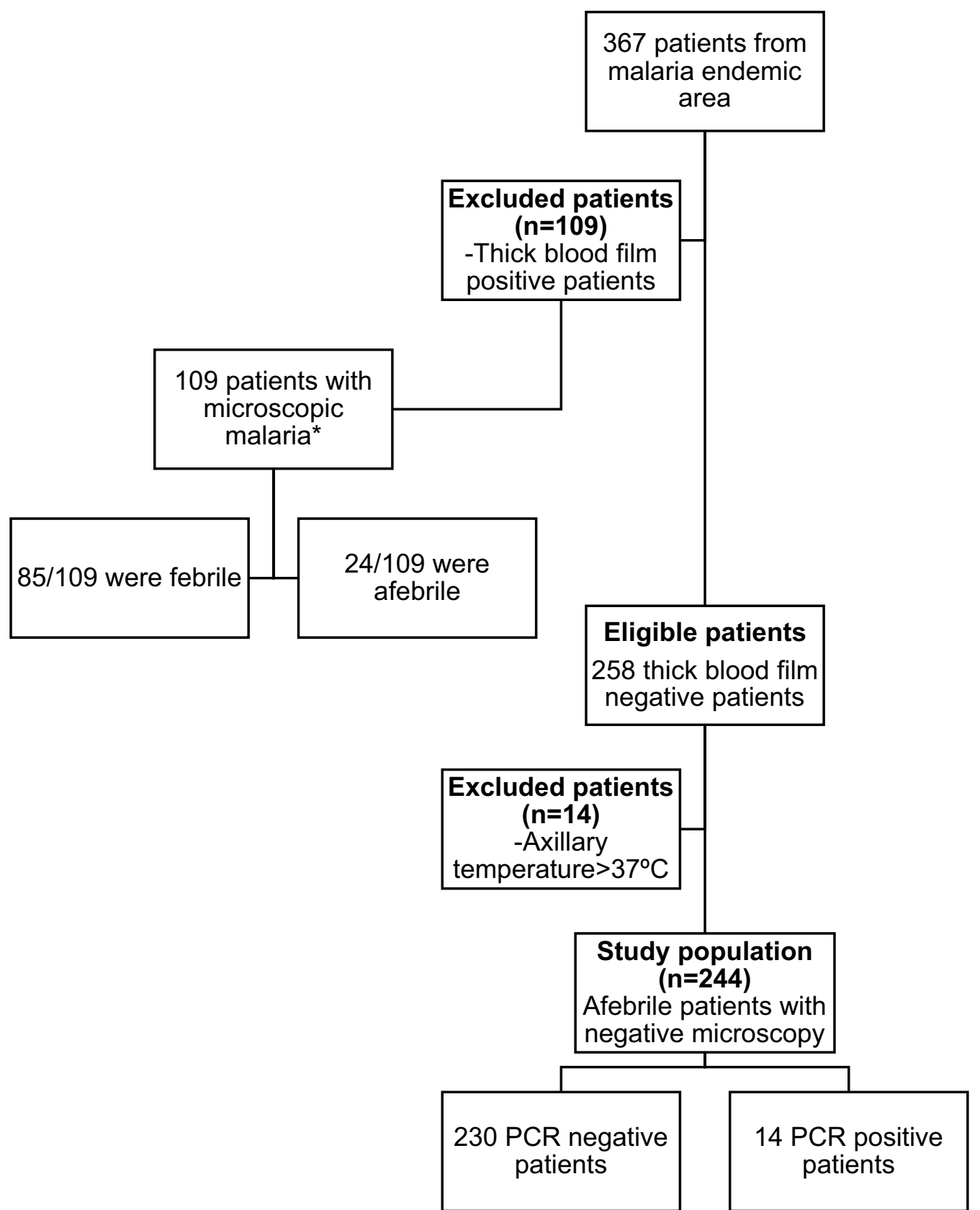

Fig. 1 Flow-chart diagram of the total included patients. *Sociodemographic, analytical and clinical features of these patients are described in additional files

(14.3\% in submicroscopic malaria vs $1.7 \%$ in negative patients $P=0.040$ ). Higher percentages of strongyloidiasis and schistosomiasis were found in submicroscopic malaria patients although these associations were not significant $(14.3 \%$ vs $5.2 \%, P=0.187$ and $14.3 \%$ vs $3.0 \%$, $P=0.087$, respectively).

The main reason for consultation of the 14 submicroscopic patients was immigrant screening, representing the $15 \%(6 / 39)$ of all patients attending the immigrant screening consultation. Among women, there was one who was pregnant. Socio-demographic, epidemiological, analytical and microbiological features of the 14 patients with submicroscopic malaria are shown in Table 5.

Ten patients $(71.4 \%)$ had $P$. falciparum submicroscopic malaria, 2 (14.3\%) patients had mixed infections (1 P. falciparum $+P$. ovale and $1 P$. falciparum, $P$. malariae $+P$. 
Table 1 Socio-demographic features of the total 244 patients and univariate analysis by subgroups

\begin{tabular}{|c|c|c|c|c|}
\hline Frequency, n (\%) & $\begin{array}{l}\text { Total } \\
\mathrm{N}=244\end{array}$ & $\begin{array}{l}\text { Patients } \\
\text { with submicroscopic } \\
\text { malaria } \\
\mathrm{N}=14\end{array}$ & $\begin{array}{l}\text { Negative patients } \\
\mathrm{N}=230\end{array}$ & $P$ value* \\
\hline Age [years], median $\left(\mathrm{IQR}^{\mathrm{a}}\right)$ & $41(33-48)$ & $41(32-45)$ & $41(23-48)$ & 0.742 \\
\hline Gender, male, n (\%) & $132(54.1 \%)$ & $8(57.1 \%)$ & $124(53.9 \%)$ & 1.000 \\
\hline Sub-Saharan origin, n (\%) & $224(91.8 \%)$ & $14(100 \%)$ & $210(91.3 \%)$ & 1.000 \\
\hline Time of residence in Spain [years], median (IQR) & $11.1(5.7-16.2)$ & $8.9(4.3-12.9)$ & $11.3(6.0-16.3)$ & 0.163 \\
\hline Travels to endemic area since first arrival in Spain (yes/no), n (\%) & $86(35.3)$ & $7(50.0)$ & $79(34.4)$ & 0.257 \\
\hline Anti-malarial chemoprophylaxis ${ }^{\mathrm{a}}, \mathrm{n}(\%)$ & $14 / 86(16.3)$ & $1 / 7(14.3)$ & $13 / 79(16.5)$ & 1.000 \\
\hline Time from last travel to endemic area ${ }^{\mathrm{b}}$ [months], median (IQR) & $6.2(3.5-9.4)$ & $4.0(3.4-6.0)$ & $6.6(3.5-9.5)$ & 0.170 \\
\hline Previous malaria, n (\%) & $104(42.6)$ & $6(42.9)$ & $98(42.6)$ & 0.160 \\
\hline
\end{tabular}

${ }^{*} P$ values $<0.05$ were considered statistically significant. Mann Whitney U-test and Fischer's exact tests were performed for quantitative and categorical variables respectively

a Patients who had returned to endemic area after first arrival in Spain were defined as the total population (denominator)

${ }^{b}$ Evaluated in patients without chemoprophylaxis intake before last time to endemic area

Table 2 Laboratory test results of the total 244 patients and univariate analysis by subgroups

\begin{tabular}{|c|c|c|c|c|}
\hline & $\begin{array}{l}\text { Total } \\
\mathrm{N}=244\end{array}$ & $\begin{array}{l}\text { Patients } \\
\text { with submicroscopic } \\
\text { malaria } \\
\mathrm{N}=14\end{array}$ & $\begin{array}{l}\text { Negative patients } \\
\mathrm{N}=230\end{array}$ & $P$ value* \\
\hline Leukocyte count $\left(\times 10^{3} / \mathrm{mm}^{3}\right)$, median (IQR) & $5.3(4.0-6.9)$ & $5.2(3.9-7.4)$ & $5.3(4.0-6.9)$ & 0.898 \\
\hline Leukopaeniaa , n (\%) & $55(22.5)$ & $4(28.6)$ & $51(22.2)$ & 0.525 \\
\hline Platelet count $\left(\times 10^{3} / \mathrm{mm}^{3}\right)$, median (IQR) & $219(172-264)$ & $204(177-243)$ & $219(172-266)$ & 0.459 \\
\hline Thrombocytopaeniab, n (\%) & $33(13.52)$ & $3(21.4)$ & $30(13.0)$ & 0.413 \\
\hline Haemoglobin level (mg/dl), median (IQR) & $13.4(12.1-14.6)$ & $14.0(12.2-15.0)$ & $13.4(12.1-14.5)$ & 0.361 \\
\hline Anaemiac, n (\%) & $65(26.6)$ & $3(21.4)$ & $62(26.9)$ & 0.765 \\
\hline
\end{tabular}

*P values $<0.05$ were considered statistically significant. Mann Whitney U-test and Fisher's exact tests were performed for quantitative and categorical variables, respectively

a Defined as $<3 \times 10^{3}$ leukocytes $/ \mathrm{mm}^{3}$

b Defined as $<150 \times 10^{3}$ platelets $/ \mathrm{mm}^{3}$

c Defined as $<13 \mathrm{mg}$ haemoglobin/dl for men and $<12 \mathrm{mg}$ haemoglobin/dl for women

Table 3 Reason for consultation of the total 244 patients and univariate analysis by subgroups

\begin{tabular}{llll}
\hline Frequency, $\mathbf{n}(\%)$ & $\begin{array}{l}\text { Total } \\
\mathbf{N = 2 4 4}\end{array}$ & $\begin{array}{l}\text { Patients with submicroscopic } \\
\text { malaria } \\
\mathbf{N = 1 4}\end{array}$ & $\begin{array}{l}\text { Negative patients } \\
\mathbf{N}=\mathbf{2 3 0}\end{array}$ \\
\hline Immigrant screening & $39(16.0)$ & $6(42.9)$ & $33(14.4)$ \\
HIV follow-up & $34(13.9)$ & $3(21.4)$ & $31(13.5)$ \\
Abdominal pain & $27(11.7)$ & 0 & $27(11.7)$ \\
Asthenia & $18(7.4)$ & $3(21.4)$ & $15(6.5)$ \\
Headache & $18(7.4)$ & $2(14.3)$ & $16(7.0)$ \\
General discomfort & $11(4.5)$ & $1(7.1)$ & $10(4.4)$ \\
Eosinophilia & $7(2.9)$ & $1(7.1)$ & 6.422 \\
Myalgia & $6(2.5)$ & $2(14.3)$ & 0.073 \\
Others & $92(37.7)$ & $2(14.3)$ & 0.276 \\
\hline
\end{tabular}

${ }^{*} P$ values $<0.05$ were considered statistically significant (in italics). Mann Whitney U-test and Fisher's exact tests were performed for quantitative and categorical variables respectively 
Table 4 Co-morbidities and other infectious diseases in the 244 afebrile patients and univariate analysis of subgroups

\begin{tabular}{|c|c|c|c|c|}
\hline Frequency, n (\%) & $\begin{array}{l}\text { Total } \\
\mathrm{N}=244\end{array}$ & $\begin{array}{l}\text { Patients with submicroscopic } \\
\text { malaria } \\
N=14\end{array}$ & $\begin{array}{l}\text { Negative patients } \\
\mathrm{N}=230\end{array}$ & $P$ value* \\
\hline Co-morbidities & $102(41.8)$ & $4(28.6)$ & $98(42.6)$ & 0.406 \\
\hline Diabetes Mellitus & $16(6.6)$ & $1(7.1)$ & $15(6.5)$ & 1.000 \\
\hline Arterial hypertension & $24(9.8)$ & $2(14.3)$ & $22(9.6)$ & 0.635 \\
\hline Dyslipidaemia & $14(5.7)$ & 0 & $14(6.1)$ & 1.000 \\
\hline Neoplasia & $8(3.3)$ & 0 & $8(3.5)$ & 1.000 \\
\hline Transplantation & $3(1.2)$ & 0 & $3(1.3)$ & 1.000 \\
\hline Other comorbidities & $72(30.8)$ & $2(15.4)$ & $70(31.7)$ & 0.354 \\
\hline \multicolumn{5}{|l|}{ Infectious diseases } \\
\hline HIV & $61(25.0)$ & $4(28.6)$ & $57(24.8)$ & 0.754 \\
\hline HBV & $34(13.9)$ & $2(14.3)$ & $32(13.9)$ & 1.000 \\
\hline $\mathrm{HCV}$ & $7(2.9)$ & $1(7.1)$ & $6(2.6)$ & 0.342 \\
\hline Tuberculosis & $20(8.2)$ & $1(7.1)$ & $19(8.3)$ & 1.000 \\
\hline Strongyloides stercoralis & $14(5.7)$ & $2(14.3)$ & $12(5.2)$ & 0.187 \\
\hline Filariasis & $6(2.5)$ & $2^{\mathrm{a}}(14.3)$ & $4^{\mathrm{b}}(1.7)$ & 0.040 \\
\hline Schistosomiasis & $9(3.7)$ & $2(14.3)$ & $7(3.0)$ & 0.087 \\
\hline Intestinal parasites & $8(3.3)$ & $1(7.1)$ & $7(3.0)$ & 0.381 \\
\hline
\end{tabular}

* $P$ values $<0.05$ were considered statistically significant (in italics). Mann Whitney U-test and Fisher's exact tests were performed for quantitative and categorical variables, respectively

a One Mansonella perstans and one lymphatic filariasis (Only serological diagnosis)

b Onchocerca spp.

ovale) and $2(14.3 \%)$ patients had Plasmodium vivax infection.

\section{Discussion}

In Spain, scarce studies have evaluated the prevalence of submicroscopic malaria in afebrile immigrants [26, 27]. These authors describe slightly different levels of prevalence than the present study, (4.6\% and $8.9 \%$ vs $5.7 \%$ ). The different performances of the molecular techniques, the chosen reference methods (simple gold-standard vs composite gold-standard), the design of the study (single-centre vs multicentre) and the inclusion criteria (the definition of "asymptomatic" and the minimal time of residence in Spain vary among these studies) are important features that could explain the differences in these prevalence levels.

According to some studies from endemic areas up to $50 \%$ of sub-clinical children carrying $P$. falciparum, could develop clinical malaria [28]. Currently there are no studies that assess the risk of developing clinical malaria in adult immigrants arriving to non-endemic areas, although some authors suggest that few afebrile adults develop symptoms after a relatively short time period [29]. In this study, anti-malarial treatment was offered to all diagnosed patients and follow-up visits were not registered in the database, so the risk of clinical relapse was not evaluated. Submicroscopic malaria caused by $P$. falciparum was detected in three patients who had not returned to endemic area in the year before consultation, noting the possibility of being pauci or asymptomatic for a long period, as described by other authors [30]. Unfortunately, due to the lack of epidemiological data, differences among the period of incubation of submicroscopic $P$. falciparum infection and mixed or non-falciparum infections were not evaluated.

Regarding analytical features, evidence from studies developed in sub-Saharan countries associates anaemia and thrombocytopaenia not only with symptomatic but also with afebrile patients with malaria [19]. In the study cohort, 3 of the 14 afebrile patients had anaemia and thrombocytopaenia but there was not statistically significant association, probably because of the low number of submicroscopic malaria cases, there is nothing to conclude about this. Further studies in non-endemic countries would be interesting on this matter. Nevertheless, statistically significant association of submicroscopic malaria with myalgia was described, which to date, has been described with febrile malaria but not with afebrile patients. The association with filarial infection has also been observed in another study, suggesting that the modulation in the immune response produced by filariasis may protect against clinical malaria [27]. More studies are needed to better understand the interactions among these parasites and the immune system. 
Table 5 Descriptive features of the 14 submicroscopic malaria cases

\begin{tabular}{|c|c|c|c|c|c|c|c|c|c|}
\hline Gender & $\begin{array}{l}\text { Age } \\
\text { (years) }\end{array}$ & $\begin{array}{l}\text { Area } \\
\text { of origin }\end{array}$ & $\begin{array}{l}\text { Time } \\
\text { of residence } \\
\text { in Spain } \\
\text { (years) }\end{array}$ & $\begin{array}{l}\text { Travels } \\
\text { to endemic } \\
\text { area in the year } \\
\text { before inclusion }\end{array}$ & $\begin{array}{l}\text { Time } \\
\text { from the last } \\
\text { travel } \\
\text { to endemic } \\
\text { area (months) }\end{array}$ & $\begin{array}{l}\text { Reason } \\
\text { for consultation }\end{array}$ & $\begin{array}{l}\text { Antimalarial } \\
\text { chemoprophylaxis } \\
\text { prior last travel } \\
\text { to endemic area }\end{array}$ & $\begin{array}{l}\text { Previous } \\
\text { malaria }\end{array}$ & Detected species \\
\hline Male & 31 & Africa (Mali) & 9.5 & Yes & 7.4 & $\begin{array}{l}\text { Immigrant screen- } \\
\text { ing }\end{array}$ & No & No & $\begin{array}{l}\text { Plasmodium } \\
\text { falciparum }\end{array}$ \\
\hline Male & 42 & $\begin{array}{l}\text { Africa } \\
\text { (Nigeria) }\end{array}$ & 16.5 & Yes & 4.5 & $\begin{array}{l}\text { Headache, } \\
\text { myalgia, others } \\
\text { (cough and } \\
\text { dyspnea) }\end{array}$ & Unknown & Yes & $\begin{array}{l}\text { Plasmodium } \\
\text { falciparum }\end{array}$ \\
\hline Male & 46 & $\begin{array}{l}\text { Africa } \\
\text { (Equa- } \\
\text { torial } \\
\text { Guinea) }\end{array}$ & 4.3 & Yes & 5.1 & Asthenia & Unknown & Unknown & $\begin{array}{l}\text { Plasmodium } \\
\text { falciparum }\end{array}$ \\
\hline Female & 44 & $\begin{array}{l}\text { Africa } \\
\text { (Equa- } \\
\text { torial } \\
\text { Guinea) }\end{array}$ & 12.9 & No & Unknown & $\begin{array}{l}\text { Immigrant screen- } \\
\text { ing }\end{array}$ & - & Yes & $\begin{array}{l}\text { Plasmodium } \\
\text { falciparum }\end{array}$ \\
\hline Female & 32 & $\begin{array}{l}\text { Africa } \\
\text { (Equa- } \\
\text { torial } \\
\text { Guinea) }\end{array}$ & 12.8 & Yes & 3.7 & Asthenia & No & Yes & $\begin{array}{l}\text { Plasmodium } \\
\text { falciparum }\end{array}$ \\
\hline Female & 50 & $\begin{array}{l}\text { Africa } \\
\text { (Equa- } \\
\text { torial } \\
\text { Guinea) }\end{array}$ & 8.9 & Yes & 2 & $\begin{array}{l}\text { Asthenia, head- } \\
\text { ache, general } \\
\text { discomfort, } \\
\text { myalgia }\end{array}$ & No & Unknown & $\begin{array}{l}\text { Plasmodium } \\
\text { falciparum }\end{array}$ \\
\hline Male & 31 & $\begin{array}{l}\text { Africa } \\
\quad \text { (Eritrea) }\end{array}$ & 0.3 & No & Unknown & $\begin{array}{l}\text { Immigrant screen- } \\
\text { ing }\end{array}$ & - & Unknown & Plasmodium vivax \\
\hline Male & 18 & $\begin{array}{l}\text { Africa } \\
\text { (Equa- } \\
\text { torial } \\
\text { Guinea) }\end{array}$ & 0.4 & No & Unknown & $\begin{array}{l}\text { Immigrant screen- } \\
\text { ing }\end{array}$ & - & No & $\begin{array}{l}\text { Plasmodium falci- } \\
\text { parum + Plas- } \\
\text { modium } \\
\text { malariae + Plas- } \\
\text { modium ovale }\end{array}$ \\
\hline Female & 45 & $\begin{array}{l}\text { Africa } \\
\text { (Equa- } \\
\text { torial } \\
\text { Guinea) }\end{array}$ & 7.6 & Yes & 6.0 & $\begin{array}{l}\text { Immigrant } \\
\text { screening and } \\
\text { eosinophilia }\end{array}$ & No & Unknown & $\begin{array}{l}\text { Plasmodium } \\
\text { falciparum }\end{array}$ \\
\hline Male & 40 & $\begin{array}{l}\text { Africa } \\
\text { (Nigeria) }\end{array}$ & 16.4 & Yes & 8.0 & HIV follow-up & Yes & Yes & $\begin{array}{l}\text { Plasmodium } \\
\text { falciparum }\end{array}$ \\
\hline Male & 42 & $\begin{array}{l}\text { Africa } \\
\text { (Nigeria) }\end{array}$ & 14.2 & No & - & $\begin{array}{l}\text { Immigrant screen- } \\
\text { ing }\end{array}$ & - & Unknown & $\begin{array}{l}\text { Plasmodium } \\
\text { falciparum }\end{array}$ \\
\hline Male & 40 & $\begin{array}{l}\text { Africa } \\
\text { (Guinea } \\
\text { Bissau) }\end{array}$ & - & Unknown & - & HIV follow-up & - & Yes & Plasmodium vivax \\
\hline Female & 62 & $\begin{array}{l}\text { Africa } \\
\text { (Equa- } \\
\text { torial } \\
\text { Guinea) }\end{array}$ & - & No & - & $\begin{array}{l}\text { Others (low back } \\
\text { pain) }\end{array}$ & - & Unknown & $\begin{array}{c}\text { Plasmodium falci- } \\
\text { parum + Plas- } \\
\text { modium ovale }\end{array}$ \\
\hline Female & 39 & $\begin{array}{l}\text { Africa (Sen- } \\
\text { egal) }\end{array}$ & 8.7 & No & - & HIV follow-up & - & Yes & $\begin{array}{l}\text { Plasmodium } \\
\text { falciparum }\end{array}$ \\
\hline
\end{tabular}

In non-endemic areas, where public health programmes have eradicated the infection, the importance of afebrile carriers also relies on the possibility of reintroduction of the infection. Although to date, the reintroduction of malaria in Europe is unlikely [31], several cases and outbreaks of autochthonous malaria have been described in the last decade [3234]. Anopheles maculipennis complex (Anopheles atroparvus being the most frequent species) is widely distributed throughout Europe and especially Spain $[35,36]$, hence the potential reintroduction of $P$. vivax (which is the only malaria species that have proved to be transmitted by An. atroparvus [37]), cannot be completely ruled out. Two of the submicroscopic cases detected in the present study were $P$. vivax infections, in contrast with other Spanish studies describing $P$. falciparum infections or mixed infections only with $P$. malariae and $P$. ovale $[26,27]$. Although it is a small 
number, they only represent a small percentage of all $P$. vivax infections since not all febrile immigrants were included, so the possibility of autochthonous transmission of malaria should be kept in mind and epidemiological and entomological vigilance should not be overlooked.

Treatment protocols for asymptomatic patients before arriving to non-endemic countries have been developed in some countries, including the USA [38]. The US Refugee Health Guidelines from 2012 [39] recommended preemptive treatment for malaria in refugees using artemether/lumefantrine, which only is effective against blood-stage parasites; hence the risk of relapses caused by the dormant liver stages of $P$. ovale and $P$. vivax remains a potential problem, and noting that, as in this cohort, an important percentage of afebrile infections can be caused by these species. In this study, $15 \%$ of asymptomatic immigrants attending an immigrant screening consultation had submicroscopic malaria, the revision and actualization of these protocols should be a priority, mainly for those with anaemia and thrombocytopaenia and for those asymptomatic or with atypical symptoms like myalgias.

The main limitation of this study was the low number of submicroscopic cases detected, limiting the possibility of statistical analysis, and the lack of epidemiological information in some of the cases because of the existing sociocultural and language barrier. It is surprising that only $43 \%$ of submicroscopic cases reported having previous malaria infections, suggesting that it could probably be due to the difficulty in communication or due to a lack of awareness of the disease. The population included in the study represents a wide range of the immigrant population living in Madrid, as it is a multicentre study with a large number of hospitals participating in it. Although, only one hospital outside Madrid is included, so maybe a broader study could recall more reliable data.

\section{Conclusion}

The prevalence of submicroscopic imported malaria found in this study was similar to that previously described by other authors in non-endemic areas in afebrile immigrants, namely $P$. vivax and $P$. ovale were involved in an important percentage of these infections. Screening protocols for afebrile immigrants with molecular techniques could be useful not only for a proper management and treatment of submicroscopic infections but also to prevent the potential reintroduction of malaria in areas where the vector is present.

\section{Additional files}

Additional file 1: Table S1. Socio-demographic features of the total 109 microscopy positive patients.

Additional file 2: Table S2. Laboratory test results of the 109 patients with microscopic malaria.

Additional file 3: Table S3. Reason for consultation of the total 109 patients with microscopic malaria.

Additional file 4: Table S4. Co-morbidities and other infectious diseases of the 109 patients with microscopic malaria.

\section{Abbreviations \\ DNA: deoxyribonucleic acid; RDTs: rapid diagnostic tests; PCR: polymerase chain reaction; VFRs: visiting friends and relatives.}

\section{Acknowledgements}

We thank Silvia García-Bujalance, Mar Lago. Rocío Martínez Ruiz and Alejandro Junco for their participation in the study, and Juana Jaliano Corraliza, Manuela Ruiz Cabanillas, María Josefa Babiano, Ana María Ruiz-Cueli and Marta Lanza

Suarez for their technical support.

\section{Authors' contributions}

APA, IF, AMD and JMR designed the study protocol. APA, IF, AMD, JMR, JJ, JC, PMR, ADI, JMAG, FJM, MCG and CC carried out the parasitological tests. JMHM, $M L$, JMRG, GRM, MCM, MC, ME, EGM, CGG, MAML. BVB, BAO and MV carried out the clinical assessment. IF, JMR and APA carried out the analysis and interpretation of the data and drafted the manuscript. All authors read and approved the final manuscript

\section{Funding}

This work was funded by projects PI14/01671, PI17/01791 and PI14CIII/00014, from the Instituto de Salud Carlos III (Ministry of Economy, Industry and Competitiveness) and cofounded by the European Regional Development Fund, and approved by the Ethics Committee of our Institution. There was no funding from the PCR manufacturers; they did not play any role in data analysis or in the reporting of the results.

\section{Availability of data and materials}

All data generated and analysed during the study are available from the corresponding author on a reasonable request.

\section{Ethics approval and consent to participate}

The study protocol was approved by the Medical and Health Research Ethics Committee (CEIC) of the Hospital Universitario 12 de Octubre and by the committees of all the other included hospitals. Formal consent was signed for each participant.

\section{Consent for publication}

All authors have approved the manuscript for submission.

\section{Competing interests}

The authors declare that they have no competing interests.

\section{Author details}

${ }^{1}$ Department of Clinical Microbiology, Hospital Universitario 12 de Octubre, Madrid, Spain. ${ }^{2}$ National Microbiology Centre, Instituto de Salud Carlos III, Majadahonda, Madrid, Spain. ${ }^{3}$ Internal Medicine Service, Hospital Universitario 12 de Octubre, Madrid, Spain. ${ }^{4}$ Hospital Universitario de Fuenlabrada, Madrid, Spain. ${ }^{5}$ Hospital Príncipe de Asturias, Alcalá de Henares, Madrid, Spain. ${ }^{6}$ Hospital Universitario Fundación de Alcorcón, Madrid, Spain. ${ }^{7}$ Hospital General Universitario Gregorio Marañón, Madrid, Spain. ${ }^{8}$ Hospital de San Pedro, Logroño, La Rioja, Spain. ${ }^{9}$ Hospital Severo Ochoa, Leganés, Madrid, Spain. ${ }^{10}$ Hospital Universitario de Getafe, Getafe, Madrid, Spain. ${ }^{11}$ Emergency Service, Hospital Universitario 12 de Octubre, Madrid, Spain. ${ }^{12}$ Nephrology and Renal Transplant Service, Hospital Universitario 12 de Octubre, Madrid, Spain. ${ }^{13}$ Infectious Diseases Service Hospital Universitario 12 de Octubre, Madrid, Spain. 
Received: 1 March 2019 Accepted: 5 July 2019

Published online: 17 July 2019

\section{References}

1. White NJ, Pukrittayakamee S, Hien TT, Faiz MA, Mokuolu OA, Dondorp AM. Malaria. Lancet. 2014;383:723-35.

2. WHO. World malaria report 2018. Geneva: World Health Organization; 2018. p. 166.

3. European Centre for Disease Prevention and Control. Surveillance atlas of infectious diseases. Solna: European Centre for Disease Prevention and Control; 2017.

4. Centro Nacional de Epidemiología Instituto de Salud Carlos III. Informe Semanal de Vigilancia 15 de enero de 2019. 2019. p. 1-11. http://www. isciii.es/ISCIII/es/contenidos/fd-servicios-cientifico-tecnicos/fd-vigilancia s-alertas/fd-boletines/fd-boletin-epidemiologico-semanal-red/pdf_2019/ IS-190115-WEB.pdf. Accessed 7 Feb 2019.

5. Mascarello M, Gobbi F, Angheben A, Concia E, Marocco S, Anselmi $M$, et al. Imported malaria in immigrants to Italy: a changing pattern observed in North Eastern Italy. J Travel Med. 2009;16:317-21.

6. Galatas B, Bassat Q, Mayor A. Malaria parasites in the asymptomatic: looking for the hay in the haystack. Trends Parasitol. 2016;32:296-308.

7. Doolan DL, Dobano C, Baird JK. Acquired immunity to malaria. Clin Microbiol Rev. 2009;22:13-36.

8. Center for Disease Control and Prevention. Malaria diagnosis \& treatment in the United States. Altanta: Center for Disease Control and Prevention; 2018.

9. Muñoz J, Rojo-Marcos G, Ramírez-Olivencia G, Salas-Coronas J, Treviño B, Perez Arellano JL, et al. Diagnóstico y tratamiento de la malaria importada en España: recomendaciones del Grupo de Trabajo de Malaria de la Sociedad Española de Medicina Tropical y Salud Internacional (SEMTSI). Enferm Infecc Microbiol Clin. 2015;33:e1-13.

10. Björkman AB. Asymptomatic low-density malaria infections: a parasite survival strategy? Lancet Infect Dis. 2018;18:485-6.

11. Lindblade KA, Steinhardt L, Samuels A, Kachur SP, Slutsker L. The silent threat: asymptomatic parasitemia and malaria transmission. Expert Rev Anti Infect Ther. 2013;11:623-39.

12. Bousema T, Okell L, Felger I, Drakeley C. Asymptomatic malaria infections: detectability, transmissibility and public health relevance. Nat Rev Microbiol. 2014;12:833-40.

13. Niang M, Thiam LG, Sane R, Diagne N, Talla C, Doucoure S, et al. Substantial asymptomatic submicroscopic Plasmodium carriage during dry season in low transmission areas in Senegal: implications for malaria control and elimination. PLOS ONE. 2017;12:e0182189.

14. Almeida ACG, Kuehn A, Castro AJM, Vitor-Silva S, Fiqueiredo EFG, Brasil LW, et al. High proportions of asymptomatic and submicroscopic Plasmodium vivax infections in a peri-urban area of low transmission in the Brazilian Amazon. Parasit Vectors. 2018;11:194.

15. Stresman GH, Stevenson JC, Ngwu N, Marube E, Owaga C, Drakeley C, et al. High levels of asymptomatic and subpatent Plasmodium falciparum parasite carriage at health facilities in an area of heterogeneous malaria transmission intensity in the Kenyan highlands. Am J Trop Med Hyg. 2014;91:1101-8

16. Okell LC, Griffin JT, Kleinschmidt I, Hollingsworth TD, Churcher TS, White $\mathrm{MJ}$, et al. The potential contribution of mass treatment to the control of Plasmodium falciparum malaria. PLoS ONE. 2011;6:e20179.

17. Santa-Olalla Peralta P, Vazquez-Torres MC, Latorre-Fandos E, Mairal-Claver P, Cortina-Solano P, Puy-Azon A, et al. First autochthonous malaria case due to Plasmodium vivax since eradication, Spain, October 2010. Euro Surveill. 2010;15:19684.

18. Monge-Maillo B, Lopez-Velez R. Is screening for malaria necessary among asymptomatic refugees and immigrants coming from endemic countries? Expert Rev Anti Infect Ther. 2011;9:521-4

19. de Mast Q, Brouwers J, Syafruddin D, Bousema T, Baidjoe AY, de Groot $\mathrm{PG}$, et al. Is asymptomatic malaria really asymptomatic? Hematological, vascular and inflammatory effects of asymptomatic malaria parasitemia. J Infect. 2015;71:587-96.

20. Sifft KC, Geus D, Mukampunga C, Mugisha JC, Habarugira F, Fraundorfer $\mathrm{K}$, et al. Asymptomatic only at first sight: malaria infection among schoolchildren in highland Rwanda. Malar J. 2016;15:553.
21. Gudo ES, Prista A, Jani IV. Impact of asymptomatic Plasmodium falciparum parasitemia on the immunohematological indices among school children and adolescents in a rural area highly endemic for malaria in southern Mozambique. BMC Infect Dis. 2013;13:244.

22. Ramirez-Olivencia G, Rubio JM, Rivas P, Subirats M, Herrero MD, Lago M, et al. Imported submicroscopic malaria in Madrid. Malar J. 2012;11:324.

23. Center for Disease Control and Prevention. Yellow Book. Traveler's Health. Map 3-09. Malaria-endemic countries in the Western Hemisphere and Map 3-10. Malaria-endemic countries in the Eastern Hemisphere. 2018

24. Martín-Díaz A, Rubio JM, Herrero-Martínez JM, Lizasoain M, Ruiz-Giardin $J M$, Jaqueti J, et al. Study of the diagnostic accuracy of microbiological techniques in the diagnosis of malaria in the immigrant population in Madrid. Malar J. 2018;17:314.

25. Zhang J, Zhang Y, Chaloner K, Stapleton JT. A sequential classification rule based on multiple quantitative tests in the absence of a gold standard. Stat Med. 2016;35:1359-72.

26. Monge-Maillo B, Norman F, Perez-Molina JA, Diaz-Menendez M, Rubio JM Lopez-Velez R. Plasmodium falciparum in asymptomatic immigrants from sub-Saharan Africa, Spain. Emerg Infect Dis. 2012;18:356-7.

27. Pousibet-Puerto J, Cabezas-Fernandez MT, Lozano-Serrano AB, VazquezVillegas J, Soriano-Perez MJ, Cabeza-Barrera I, et al. Submicroscopic malaria in migrants from sub-Saharan Africa, Spain. Emerg Infect Dis. 2019;25:349-52.

28. Njama-Meya D, Kamya MR, Dorsey G. Asymptomatic parasitaemia as a risk factor for symptomatic malaria in a cohort of Ugandan children. Trop Med Int Health. 2004;9:862-8.

29. Galatas B, Martí-Soler H, Nhamussua L, Cisteró P, Aide P, Saute F, et al. Dynamics of afebrile Plasmodium falciparum infections in Mozambican men. Clin Infect Dis. 2018;67:1045-52.

30. Dauby N, Figueiredo Ferreira M, Konopnicki D, Nguyen VTP, Cantinieaux B, Martin C. Delayed or recurrent Plasmodium falciparum malaria in migrants: a report of three cases with a literature review. Am J Trop Med Hyg. 2018;98:1102-6.

31. European Center for Disease Prevention and Control. Consultation on transmission risk in Europe. Meeting report. 2012. https://ecdc.europa.eu/ sites/portal/files/media/en/publications/Publications/MER-Malaria-meeti ng.pdf. Accessed 26 Mar 2019.

32. Andriopoulos P, Economopoulou A, Spanakos G, Assimakopoulos G. A local outbreak of autochthonous Plasmodium vivax malaria in Laconia, Greece - a re-emerging infection in the southern borders of Europe? Int J Infect Dis. 2013;17:e125-8.

33. Velasco E, Gomez-Barroso D, Varela C, Diaz O, Cano R. Non-imported malaria in non-endemic countries: a review of cases in Spain. Malar J. 2017;16:260.

34. Olaso A, Ramos JM, Lopez-Ballero MF, Olaso I. Malaria in Europe: followup of autochthonous malaria in Greece and new risks. Enferm Infecc Microbiol Clin. 2017;35:543-4.

35. European Center for Disease Prevention and Control. Anopheles atroparvus_factsheet for experts. 2014. https://ecdc.europa.eu/en/disea se-vectors/facts/mosquito-factsheets/anopheles-atroparvus. Accessed 26 Mar 2019.

36. Bueno-Mari R, Jimenez-Peydro R. Study of the malariogenic potential of Eastern Spain. Trop Biomed. 2012:29:39-50.

37. de Zulueta J, Ramsdale CD, Coluzzi M. Receptivity to malaria in Europe. Bull World Health Organ. 1975;52:109-11.

38. Stauffer WM, Weinberg M, Newman RD, Causer LM, Hamel MJ, Slutsker L, et al. Pre-departure and post-arrival management of P. falciparum malaria in refugees relocating from sub-Saharan Africa to the United States. Am J Trop Med Hyg. 2008;79:141-6.

39. Center for Disease Control and Prevention. Domestic refugee health guidelines: malaria. Atlanta: Center for Disease Control and Prevention; 2012.

\section{Publisher's Note}

Springer Nature remains neutral with regard to jurisdictional claims in published maps and institutional affiliations. 